\title{
Impact of anthropogenic disturbances on the diversity of shallow stony corals in the Veracruz Reef System National Park
}

\section{Impacto de perturbaciones antrópicas sobre la diversidad de corales pétreos superficiales en el Parque Nacional Sistema Arrecifal veracruzano}

\author{
Carla V. Gutiérrez-Ruiz ${ }^{1,2}$, Miguel A. M. Román-Vives ${ }^{2}$, Carlos H. Vergara ${ }^{1}$ and Ernesto I. Badano ${ }^{3 *}$ \\ ${ }^{1}$ Departamento de Ciencias Químico Biológicas, Escuela de Ingeniería y Ciencias, Universidad de las Américas Puebla, Ex. Hda. Sta. Catarina Mártir, \\ 72820 San Andrés Cholula, Puebla, Mexico. \\ ${ }^{2}$ Acuario de Veracruz, Blvd. Manuel Ávila Camacho s/n, Playón de Hornos, 91910 Veracruz, Veracruz, Mexico. \\ ${ }^{3}$ División de Ciencias Ambientales, Instituto Potosino de Investigación Cientifica y Tecnológica, Camino a la Presa San José 2055, Colonia Lomas 4ta \\ Sección, 78216 San Luis Potosí, San Luis Potosí, Mexico. \\ *Correspondent: ernesto.badano@ipicyt.edu.mx
}

\begin{abstract}
Anthropogenic disturbances may affect the development and maintenance of coral reefs by promoting diseases and other syndromes. In turn, this may cause local decreases in coral species diversity. In this study, we compared the prevalence of syndromes (including diseases and non-disease syndromes) and the diversity of stony coral species between reefs located close (Sacrificios reef) and far away (Santiaguillo reef) of the port of Veracruz, Mexico. The prevalence of syndromes was higher at Sacrificios than at Santiaguillo, and it also increased with the abundance of coral colonies at the former reef. On the other hand, coral diversity was lower at Sacrificios than at Santiaguillo, suggesting that anthropogenic disturbances, besides promoting diseases and other syndromes, also lead to local decreases in species diversity.
\end{abstract}

Key words: biodiversity, bleaching, conservation, diseases, Gulf of Mexico.

Resumen. Las perturbaciones antropogénicas pueden afectar el desarrollo y mantenimiento de los arrecifes de coral mediante la promoción de las enfermedades y otros síndromes. A su vez, esto puede producir un descenso en la diversidad local de especies. En este estudio, se comparó la prevalencia de síndromes (tanto aquellos causados por enfermedades, como por otros factores) y la diversidad de especies de corales pétreos entre arrecifes ubicados cerca (Sacrificios) y lejos (Santiaguillo) del puerto de Veracruz, México. La prevalencia de síndromes fue mayor en Sacrificios que en Santiaguillo, y también se incrementó con la abundancia de colonias de coral en Sacrificios. Por otra parte, la diversidad de corales fue menor en Sacrificios que en Santiaguillo, sugiriendo que las perturbaciones antropogénicas, además de promover las enfermedades y otros síndromes, también disminuyen localmente la diversidad de especies.

Palabras clave: biodiversidad, blanqueamiento, conservación, enfermedades, golfo de México.

\section{Introduction}

Coral reefs are biogenic marine structures composed by hermatypic scleractinian organisms (Phylum Cnidaria:

Recibido: 15 abril 2009; aceptado: 01 junio 2010
Class Anthozoa) and their calcareous deposits (Sebens, 1994). They are usually composed by colonies of several species and provide food, habitat, substrate and shelter for other organisms (Loya, 1972; Porter, 1972; Connell, 1978). For these reasons, coral reefs are considered the most diverse and complex ecosystems of marine environments, and they are the target of international conservation efforts 
(International Society for Reef Studies, 2004).

The diversity and cover of these reefs have declined over the past few decades (Sebens, 1994). Such changes have been attributed to multiple factors, including direct and indirect impacts of anthropogenic disturbances (Porter and Meier, 1992; Sebens, 1994; Ostrander et al., 2000; GarzónFerreira et al., 2001; Nyström and Folke, 2001; Sandin et al., 2008). Global climate change is the main indirect human-induced disturbance affecting corals (Brown, 1997; Harvell et al., 1999, 2002; Graham et al., 2006; Bruno et al., 2007). However, while this factor affects marine biota at large temporal scales, local anthropic disturbances are expected to have short-term impacts on corals (Harvell et al., 2002; Nyenzi and Lefale, 2006; Bruno et al., 2007).

Coral reefs located near cities or highly industrialized areas are known to be strongly affected by local anthropogenic disturbances. This is due to the increased loading of sediments, nutrients (e.g., nitrogen and phosphorus) and contaminants (heavy metals, pesticides and fertilizers) into oceans (Sebens, 1994; Connell, 1997; Guzmán and Guevara, 1998; Gómez et al., 2001; Porter et al., 2001; Martínez and Acosta, 2005). These disturbances, in turn, may increase the mortality of reef-forming corals by promoting diseases (e.g., etiologies caused by fungus, bacteria and viruses) and/or non-disease syndromes that preclude the performance of polyps (e.g., bleaching) (Richmond, 1993; Harvell et al., 1999, 2002; Nyström and Folke, 2001; Pandolfi, 2002; Bruno et al., 2003; Aronson et al., 2005). Under this scenario, the impacts of diseases and other syndromes should decrease with increased distance to human-impacted areas, leading to higher diversity of coral species. If so, the reefs located far away from human settlements should be the target of marine biodiversity conservation efforts, acting as core sites within larger natural protected areas. However, the reefs located near human-disturbed sites must also be included within these protected areas, being the focus of restoration actions and rational use. This strategy would allow the sustainable of marine protected areas, as stated by the Mexican legal regulations (Ley General del Equilibrio Ecológico y la Protección al Ambiente, Diario Official de la Federación, 2008).

In this study we focused on a natural protected, the Veracruz Reef System National Park area located in the Gulf of Mexico. The reefs that compose this system differ in their distances to the city and the port of Veracruz, and it has been suggested that those reefs closer to the port are highly degraded (Instituto Nacional de Ecología, 2005). In order to test our hypothesis, we assessed the prevalence of syndromes and the diversity of species of 2 shallow stony coral assemblages located at different distances from the city of Veracruz. We focused on shallow coral assemblages because, although they are more susceptible to anthropogenic disturbances (Hernández-Delgado et al., 2008) and they usually show faster recovery rates than those coral assemblages at higher depths (Pastorok and Bilyard, 1985).

\section{Materials and methods}

Study area. The Veracruz Reef System National Park is located in the southwestern section of Gulf of Mexico, in the continental shelf of the state of Veracruz. It has 52238 ha and is composed by 23 reefs distributed across the municipalities of Veracruz, Boca del Río and Alvarado (Horta-Puga et al., 2007; Tunnel, 2007). The port of Veracruz concentrates up to $30 \%$ of the maritime commercial traffic of Mexico but, besides this intense marine traffic, several industries (textile, metallurgic and food) also dump their residues in the ocean, together with part of the city sewage. Furthermore, 3 main rivers (Papaloapan, La Antigua and Jamapa) discharge their waters in this area, contributing with sediments, heavy metals, agricultural and industrial contaminants and sewage loads from inland cities (RosalesHoz et al., 2007). Other impacts include ship groundings, oil spills and overfishing (Martínez-Caballero, 2007).

This study was focused on 2 coral reefs of the Veracruz Reef System: Sacrificios (19¹0'26" N; 96 05'32" W) and Santiaguillo (19 $\left.08^{\prime} 30^{\prime \prime} \mathrm{N} ; 9^{\circ} 48^{\prime} 35^{\prime \prime} \mathrm{W}\right)$. The Sacrificios reef belongs to the northern section of the system, located $2.4 \mathrm{~km}$ to the south-east of the terminal ports of Veracruz. It covers $0.4 \mathrm{~km}^{2}$ and is mainly composed by coral rubble and sand (Tunnel, 2007). This reef has a small cay at its southern section, densely vegetated with exotic grasses (Tunnel, 2007), where a lighthouse was established 4 centuries ago (Vargas-Hernández et al., 1993). The Sacrificios reef is of particular interest since it was the target of human activities for many years. Ever since the Spanish conquest, people extracted the madreporic substrate of this reef for constructing houses, fortresses, and other defenses for the city (Carricart-Gavnivet, 1998). In second half to the 20th century, this reef was one of the main centers for scuba tourism in Veracruz. However, the continuous degradation led the closing of this reef to the tourism in 1982 (HortaPuga and Barba-Santos 2006). Currently, the Sacrificos reef is directly affected by pollutants of the port and the City of Veracruz, as well as the sewage discharges of the treatment plant at Bahía de Vergara, located near the port (Rosales-Hoz et al., 2009).

The Santiaguillo reef, on the other hand, is located 19.7 $\mathrm{km}$ to the south-east of the city of Veracruz and belongs to the southern section of the Reef System. It covers $1.0 \mathrm{~km}^{2}$ 
and lies offshore from the fishing village of Antón Lizardo (Tunnel, 2007). The reef has a small cay, almost totally composed of coral rubble, and shows no vegetation except for Sesuvium sp. (sea purslane) (Tunnel, 2007). Although the reef has a lighthouse on its cay, it shows no signs of coral extraction and seems to be one of the best preserved of this systems (M. A. M. Román-Vives, personal observation). Furthermore, although there are no formal studies about the impacts of pollutants at Santiaguillo, it is feasible that the impact of sewage discharges and pollutants are lower than at Sacrificios due to the remoteness of this reef (Linton et al., 2002; Horta-Puga, 2007; Jones et al., 2008).

Sampling. Both reefs were sampled in summer of 2006 to assess the prevalence of syndromes and the local diversity of stony corals. For this, $3100 \mathrm{~m}$ parallel transect lines located at 3,6 and $9 \mathrm{~m}$ depth were laid out at the windward exposure of each reef. Three additional transects were laid out at the leeward exposure of the reefs following the same procedure (6 transects per reef in total). The starting point of transects was randomly chosen at each reef exposure. Transects were divided into 10 equivalent segments (10m long each) and 5 sampling plots of $20 \mathrm{~m}^{2}$ were established on each transect (see Fig. 1 for details).

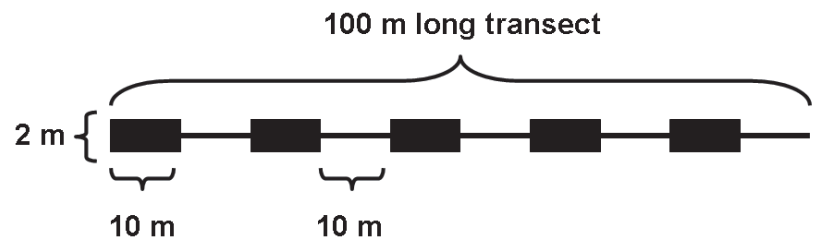

Figure 1. Sampling design used to determine the abundance of coral species; sampling plots (in black) were $10 \mathrm{~m}$ long x $2 \mathrm{~m}$ wide, spaced $10 \mathrm{~m}$ from each other along the $100 \mathrm{~m}$ transects.

All coral colonies within sampling plots were identified to the lowest taxonomic level that was possible in the field following the criteria proposed by Humann and DeLoach (2001). The number of colonies of each species was counted to estimate their abundances. During sampling, it was also assessed whether each colony was healthy or not and, in the later case, the kind of syndrome affecting the respective colony was recorded (descriptions and pictures of syndromes are in the Appendix). Sampling was carried out by direct immersion with scuba diving gear and determinations of coral species were performed in the field by 2 observers. Data from windward and leeward exposures of each reef were later pooled in a single database for performing the analyses. We used this method because we were interested in performing comparisons among reefs, but not between different exposures of the reefs.

Statistical analyses. To determine whether the prevalence of syndromes differed between the reefs of Sacrificios and Santiaguillo, we conducted Chi-square tests for $2 \times 2$ contingency tables. We first compared the total frequency of coral colonies affected by syndromes between reefs. Later, a similar analysis was used to compare the prevalence of each kind of syndrome between reefs. Finally, the prevalence of syndromes was compared between reefs for each coral species. Nevertheless, these later comparisons were not performed using the Chi-square test because some species showed very low numbers of colonies affected by syndromes $(<5$; see Table 1$)$ and, therefore, the results may be strongly biased. Instead, we used the Fisher's exact test for performing these comparisons.

We later assessed if the prevalence of syndromes at each reef was related to the abundance of colonies of each coral species, and these relationships were compared between reefs. For this, a multiple regression analysis with categorical variables was performed. In this analysis, the number of colonies of each coral species affected by syndromes was the dependent variable, the total number of colonies of the respective coral species was the continuous predictive variable, and the reefs (Sacrificios vs. Santiaguillo) constituted the 2 levels of the categorical predictive variable. The regression model also included a multiplicative interaction term between predictive variables to account for differences in the slopes of regression functions obtained for each level of the categorical variable (Neter et al., 1996). This analysis allowed for an estimate of a linear regression function for the relationships between the number of colonies affected by syndromes and the total number of colonies at each reef. Furthermore, these functions are indicated to differ if the estimated parameters (intercepts or slopes) show significant differences between reefs. Differences between regression parameters were assessed with t-tests (Neter et al., 1996). All analyses described above were conducted with the software R 2.3 (R development Core Team, 2005).

To determine whether diversity of coral species varied between Sacrificios and Santiaguillo, we estimated the species richness $(S)$, the index of proportional diversity of Shannon-Wiener $\left(H^{\prime}\right)$ and a dominance index $(D)$ for each reef. To avoid biases due to differences in sampling efforts, which may occur because differences in the total number of colonies detected at each reef and/or differences in the cover of coral species, all these community attributes were computed by using individual-based rarefactions (Gotelli and Colwell, 2001). Since coral colonies may contain millions of individuals, community attributes were calculated considering each colony as an individual. Rarefactions analyses are based in Montecarlo resampling, where $S, H^{\prime}$ and $D$ are estimated as the sampling size (i.e., the number of colonies in a resample $=n$ ) decreases from a 
maximum value that is determined by the total number of individuals $(N)$ detected in the sample (Gotelli and Colwell, 2001). Rarefactions were performed with the software EcoSim 7.72 (Gotelli and Entsminger, 2005), and each value of $S, H^{\prime}$ and $D$ was computed 1,000 times for each value of $n$, from $N$ to 1 individuals. The 1,000 values of $S$ estimated at each level of $n$ were then averaged to estimate the mean species richness at each sampling size. The Shannon-Wiener diversity index for each of the 1,000 resamples of size $n$ was calculated using natural logarithms as

$$
H^{\prime}=\sum_{i=1}^{S} \dot{p} \ln (\dot{p}),
$$

were $p i$ is the proportion of individuals of the $i^{\text {th }}$ species in the sample (Magurran, 2004); the 1,000 values of $H^{\prime}$ estimated at each level of $n$ were then averaged. The species dominance index $(D)$ was calculated as the fraction of the (resampled) collection that was represented by the most common species at each rarefaction run (Gotelli and Entsminger, 2005), and it was estimated in the same way than described for $S$ and $H^{\prime}$. To assess variations in community attributes as the number of coral colonies included in resamples decreases from $N$ to 1 , we constructed rarefaction curves by plotting the average values of $S, H^{\prime}$ and $D$ against their respective values of $n$. It is important to note that, if these rarefaction curves reach an asymptote, it can be assumed that the sampling size was large enough to fully capture the diversity and composition of the target species assemblages (Colwell and Coddington, 1994). To assess statistical differences in coral species diversity between reefs, the $95 \%$ confidence intervals were calculated for each community attribute at each value of $n$, and significant differences between reefs were assumed if their confidence intervals did not overlap (Gotelli and Entsminger, 2005). Since $N$ may vary among reefs, all statistical comparisons were performed at similar values of $n$ (Gotelli and Colwell, 2001).

\section{Results}

At the Sacrificios reef, a total of 18 stony coral species were detected, while 21 species were recorded at the Santiaguillo reef; 17 species were shared between reefs (Table 1). The most abundant species at Sacrificios was Montastraea cavernosa, which was found at both reefs (Table 1). On the other hand, the most common species at Santiaguillo was Agaricia agaricites, which was only detected at this reef (Table 1). Three well recognized diseases were recorded in the reefs under study: White
Plague, Dark-Spot and Tumors (this last category included hyperplasy and neoplasy). Additionally, Bleaching, Old Dead and one unidentified syndrome, which we called Paleness, were detected on corals. Description of diseases and the other syndromes are given in the Appendix.

The total prevalence of bad health coral conditions was significantly higher at Sacrificios than at Santiaguillo (Table 1). Indeed, in the specific analyses, 5 species that were present in both reefs (Madracis decactis, M. cavernosa, Porites astreoides, $P$. porites and Stephanocoenia michelinii) showed significantly higher prevalence of syndromes at the Sacrificios reef (Table 1). No shared species showed a higher prevalence of bad health conditions at the Santiaguillo reef.

The most common syndromes affecting coral colonies in both reefs were Old Death and Bleaching, but they showed significantly higher values of prevalence at Sacrificios than at Santiaguillo (Fig. 2). At the former reef, the species with the highest abundance ( $M$. cavernosa) showed higher prevalence of syndromes than other less abundant species (Table 1). In contrast, the colonies of

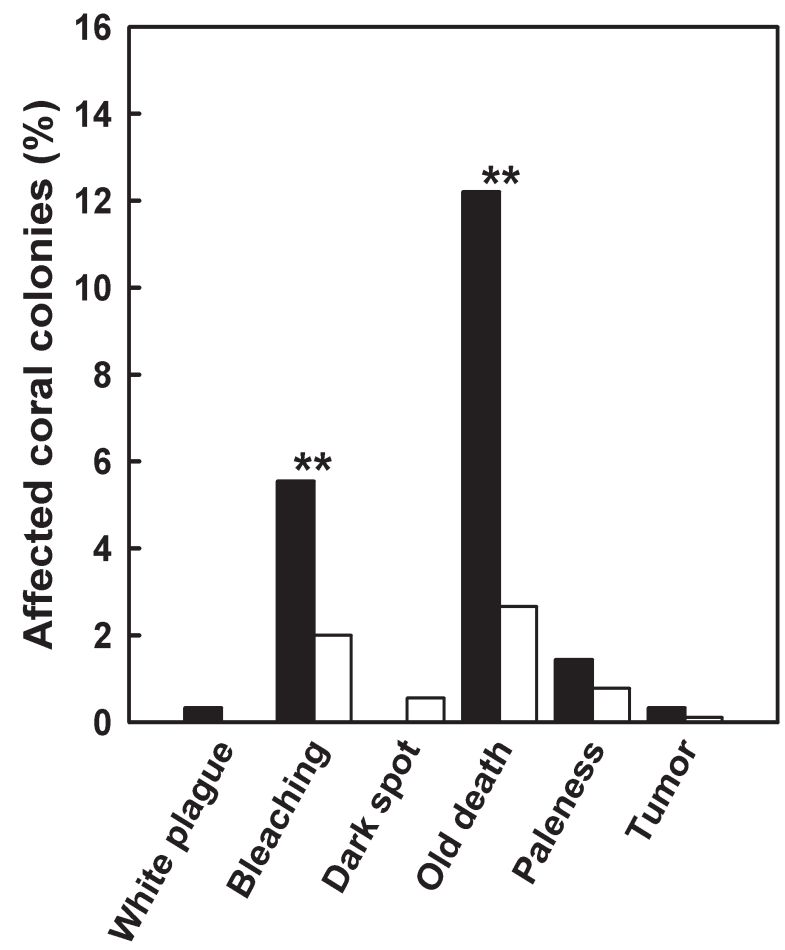

Figure 2. Prevalence of the different diseases and non-disease syndromes that affect corals in the reefs of Sacrificios (black bars) and Santiaguillo (white bars). Significant statistical differences are indicated in the figure (critical $\square$ for statistical differences $=$ $0.05 ; *=\mathrm{p}<0.05 ; * *=\mathrm{p}<0.01)$. 
the most abundant species at the Santiaguillo reef ( $A$. agaricites) showed no signs of bad conditions (Table 1).

Multiple regression analyses indicated that the prevalence of diseases and other syndromes increased with the number of colonies of the different coral species (goodness of fit ANOVA: $\mathrm{F}_{3.40}=49.738 ; \mathrm{p}<0.001 ; \mathrm{R}^{2}=$ 0.788). Significant differences were detected between slopes of regression functions obtained at each reef $\left(t_{1,40}\right.$ $=7.102 ; \mathrm{p}<0.001)$, indicating that this relationship was stepper at Sacrificios than at Santiaguillo (Fig. 3). No differences were observed between the intercepts of regression functions $\left(t_{1,40}=0.429 ; p=0.670\right)$. This indicates that the less abundant species are slightly affected by diseases and other syndromes in both reefs.

Rarefaction curves for all community attributes (species richness, diversity and dominance) reached asymptotes after 400 individuals (Fig. 4). This indicates that the sampling effort performed in the field was large enough to fully capture the variability in composition and diversity of the shallow coral assemblages. Moreover, all community attributes showed significant differences between the reefs (Fig. 4). The species richness and the Shannon-Wiener index were higher at the Santiaguillo reef

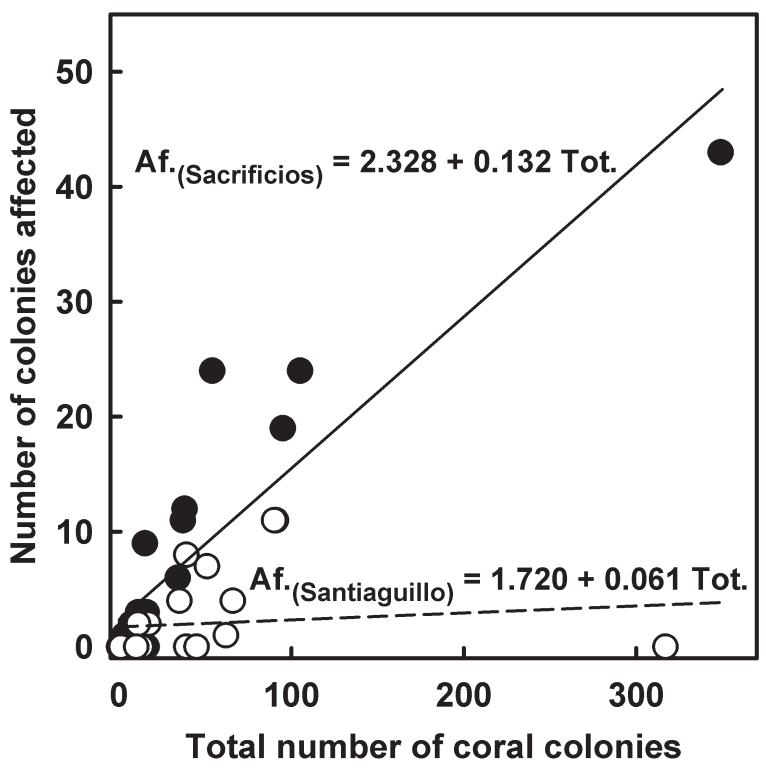

Figure 3. Relationships between the total number of colonies of each coral species and the respective number of colonies affected by syndromes at the reefs of Sacrificios (black symbols - solid line) and Santiaguillo (white symbols - dashed line). Regression functions obtained for each reef are shown in the figure (Af. = number of colonies affected by diseases; Tot. $=$ total number of colonies).
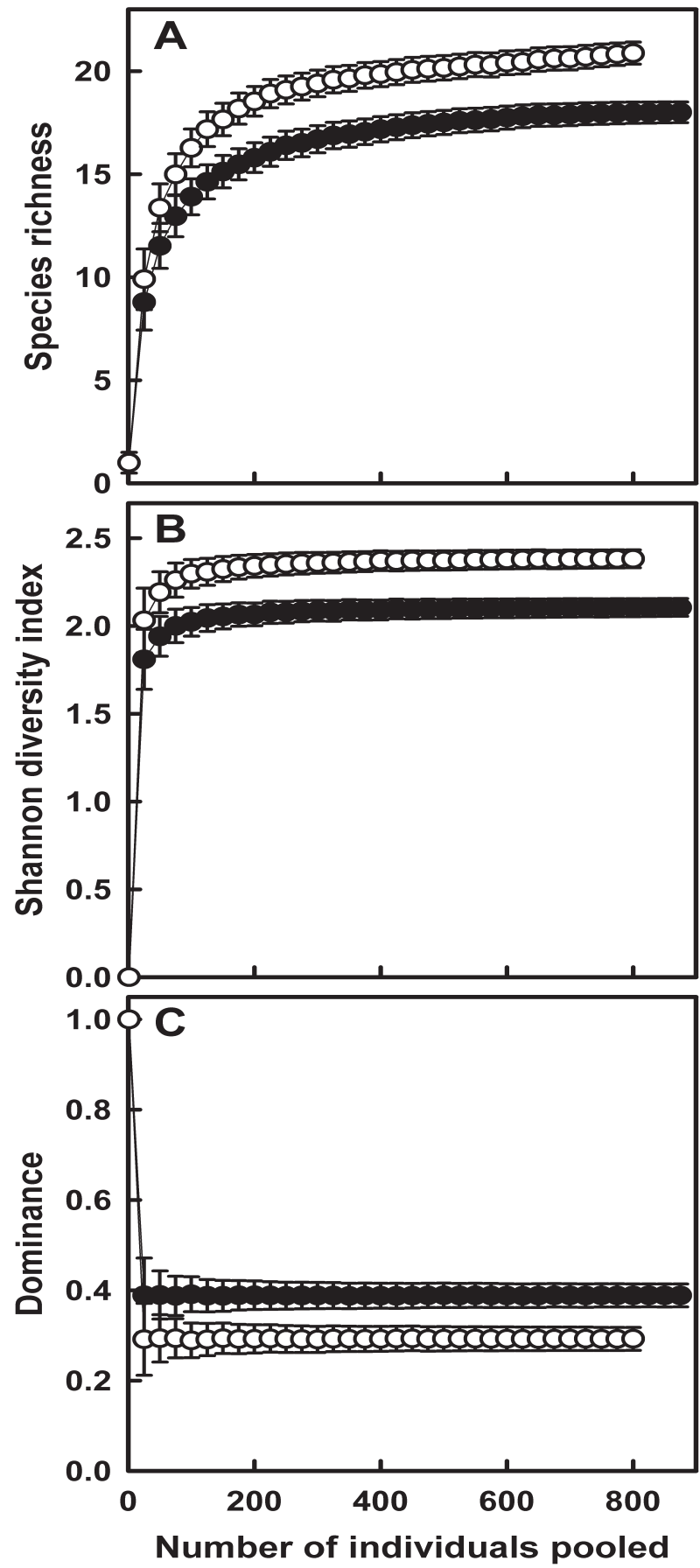

Figure 4. Rarefaction curves indicating the average values ( $\pm 95 \%$ confidence intervals) of coral species richness (A), the ShannonWiener index of proportional diversity (B) and species dominance (C) estimated at each sampling size (number of individuals) for Sacrificios (black symbols) and Santiaguillo (white symbols). Significant differences were assumed if $95 \%$ confidence intervals did not overlap between reefs at a given number of individuals. 


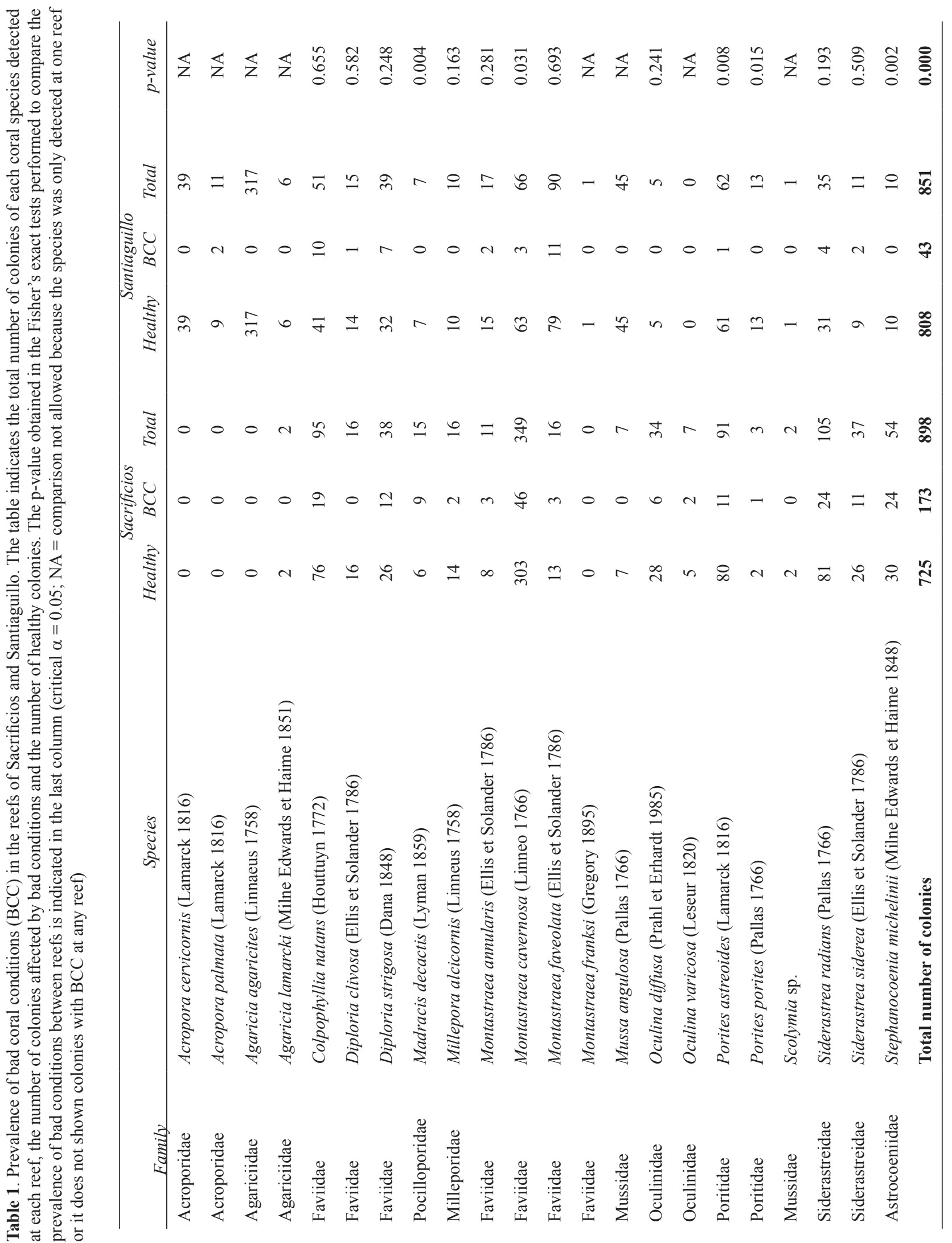


than at the Sacrificios reef, while the species dominance was lower in the former reef.

\section{Discussion}

This study indicates that assemblages of stony corals at the Sacrificios reef are more affected by diseases and other syndromes than those at the Santiaguillo reef. Moreover, the analyses of all community attributes indicated that the coral diversity is higher at Santiaguillo. These results may be explained, in part, by the fact that the northern section of this reef system is near to the city of Veracruz, and these reefs have been heavily impacted by humans over the last 4 centuries. In contrast, the reefs offshore near Antón Lizardo, in the southern section of the Veracruz Reef System, are in better conservation conditions since they are not within commercial routes of navigation or subjected to strong tourism activities (Chávez et al., 2007).

Several authors have pointed out that increases in bad health coral conditions lead to increased mortality, causing changes in species composition of reefs and declines in local species diversity (Connell, 1997; Allison et al., 2003; Aronson et al., 2005). The sewage discharges near the port of Veracruz may be one of the main responsible factors causing the highest impact of coral syndromes at the Sacrificios reef. Sewage dumping leads to nutrient enrichment of waters and may increase coral mortality by boosting bacterial infections (Pastorok and Bilyard, 1985; Bruno et al., 2003). Moreover, sewage also increases suspended solid sediments in the water column and the concentration of toxic substances, which may cause the expulsion of symbiotic zooxanthellae algae and, consequently, lead to bleaching and death of coral organisms (Garzón-Ferreira et al., 2001; Szmant, 2002).

The most common syndrome affecting coral colonies was, however, Old Death. This syndrome, while it is not considered a disease caused by microorganism (e.g., bacteria), is an important abnormal condition that affected corals in both studied reefs. It is easy to identify because colonies, or parts of them, are covered with a thick layer of sediments and algae but, once this layer is scraped off, coral skeletons show signs that indicate that the death of polyps was not recent. This syndrome is probably associated with increased sedimentation and the subsequent invasion by turf algal-sediment mats, which is a space-competition process between corals and algae that can kill the whole coral colonies (Dustan, 1999; Roy, 2004). However, since we were unable to determine whether the Old Death syndrome was caused by invading algae or other causes, in this study we have referred it as a single syndrome.
Irrespectively of its causes, this syndrome is very common along the Veracruz Reef System and its high prevalence was related to the recurrent natural disturbances that affect this region, such as hurricanes and the cold north winds that predominate during the winter months (Horta-Puga, 2003). Therefore, the commonness of the Old Death could be a consequence of cumulative events over several years (Ronzón-Rodríguez and Vargas-Hernádez, 2007). However, our analyses indicated that the prevalence of this syndrome was 10 times higher at Sacrificios than at Santiaguillo. Therefore, it is feasible that the increased sedimentation and pollution rates reported near to the Veracruz city enhance the prevalence of this syndrome at the Sacrificios reef.

The differences in the prevalence of coral syndromes between reefs could be due to the higher susceptibility of a few species rather than the whole coral community. In the analyses of the specific impact of coral syndromes, just 5 of the 16 species that were shared between reefs showed higher frequency of affected colonies at the Sacrificios reef (see Table 1). This suggests that some species are more vulnerable than others to syndromes. Also, while the prevalence of these conditions was a function of the abundance of each coral species at Sacrificios, this relationship was not detected at Santiaguillo. This means that the probability of collecting randomly an affected or healthy coral at Sacrificios, is a function of the species and its abundance. In contrast, at Santiaguillo, such an affect seems not depend on the coral species or its abundance. Thus, the factors that preclude coral survival seem to have deeper impacts on those species that are more abundant at the Sacrificios reef, while they appear to be densityindependent at the Santiaguillo reef.

Although this study is limited to the shallow coral species assemblages, the results contradict those of some studies previously conducted in this reef system. For example, Horta-Puga (2003) reported that the prevalence of the Old Death syndrome at Sacrificios oscillates between $35 \%$ and $43 \%$. In our study, the prevalence of this syndrome was lower than $13 \%$ at this reef. This author also reported lower values of bleaching (among 1.0\% and $4.5 \%)$ than this study (6\%) for the Sacrificios reef. Finally, Horta-Puga (2003) indicated that no coral colony was affected by diseases (white plague, tumors, dark spot or others) at this reef. Our results, in contrast, indicated that up to $1 \%$ of coral colonies at Sacrificios, and up to $6 \%$ at Santiaguillo, were affected by some of these diseases. The higher frequency of diseases at the Santiaguillo than at the Sacrificios reef concurs with the results of a recent study conducted by Rangel-Avalos et al. (2008). These authors indicated that the stony corals of reefs located closer to the city of Veracruz are more affected by diseases than those 
closer to Antón Lizardo. Moreover, they indicated that the Dark -Spot is the most prevalent disease on reefs at the Antón Lizardo section, and our results also support this suggestion.

Comparisons of community attributes suggest strong differences in diversity and structural composition of coralline communities associated to the studied reefs. Four species were only detected at the Santiaguillo reef (Acropora cervicornis, A. palmata, A. agaricites and Montastraea franksi), and their absence at the Sacrificios reef may cause the observed decline in richness at this reef. This suggestion is reinforced by the fact that the accumulated number of species in rarefaction curves reached an asymptote at relatively low numbers of individuals (ca. 300 individuals), so as the differences in species richness between reefs are not likely related with insufficient sampling effort. This allows the suggestion that these 4 species were present in Sacrificios in the past, but they became extinct as human intervention increased over time.

The Sacrificios reef also showed higher values of species dominance than the Santiaguillo reef. These differences may be also related with greater impacts of human activities and the elevated prevalence of syndromes affecting corals at the later reef. For example, the local extinction of a previously dominant species in Sacrificios may have released space for the recruitment of subordinate species, which become dominant in this new, highly impacted environment. Evidence for this, is that the dominant species at the Santiaguillo reef was not recorded at Sacrificios.

These differences in species richness and dominance could be related to the observed differences in the values of the index of proportional diversity of Shannon-Wiener $\left(H^{\prime}\right)$. This index is positively related with increases in species richness, while it is negatively related with increases in species dominance (Stirling and Wilsey, 2001). As a result, the lower values of the $H^{\prime}$ obtained at the Sacrificios reef can be a consequence of both, the reduced species richness and the elevated dominance observed at this site.

The Caribbean Sea and the Gulf of Mexico are considered as hot-spots of coral diseases due to the high frequency of epizootic events and fast emergence of new diseases (Harvel et al., 1999). Thus, urgent research addressing the causes and potential consequences of this phenomenon is required. Within this framework, our study suggests that human-induced disturbances are promoting the prevalence of coral syndromes. Moreover, we also suggest that such an effect may be linked to the observed decline in coral diversity at reefs located near to the city of Veracruz. It is important to indicate that conservation efforts should focus on the reefs located further away from sources of anthropogenic disturbances (i.e., Santiaguillo), which would maintain healthier environmental conditions and, consequently, higher coral diversity. On the other hand, environmental impact assessment and risk evaluations should be conducted as soon as possible to determine the possibilities of restoring reefs at the northern sections of this system (i.e., Sacrificios).

This study suggests that the distance to the source of anthropogenic disturbances is, putatively, a factor that promotes the prevalence of coral syndromes while decreases the diversity of these communities. However, it is important to recognize that both diseases and coral diversity may be also influenced by differences in the oceanographic conditions that affect the reefs of this system (see Salas-Pérez and Granados-Baraba, 2008; Ortiz-Lozano et al. 2009). Therefore, more research is required in order to determine the exact causes of the observed patters of diseases and diversity of corals in the Veracruz Reef System.

\section{Acknowledgements}

The authors thank the staff of the Aquarium of Veracruz (México) for the logistic support and materials provided during the sampling, and Nayeli Prieto for checking the orthography, grammar and style of the manuscript. We also thank the constructive comments from 3 anonymous reviewers that contributed to improve the quality of this article.

\section{Literature cited}

Allison, G. W., S. D. Gaines, J. Lubchenco and H. P. Possingham. 2003. Ensuring persistence of marine reserves: catastrophes require adopting an insurance factor. Ecological Applications 13:S8-S24.

Aronson, R. B., I. G. Macintyre, S. A. Lewis and N. L. Hilbun. 2005. Emergent zonation and geographic convergence of coral reefs. Ecology 86:2586-2600.

Brown, B. E. 1997. Coral bleaching: causes and consequences. Coral Reefs 16:S129-S138.

Bruno, J. F., L. E. Petes, C. D. Harvell and A. Hettinger. 2003. Nutrient enrichment can increase the severity of coral diseases. Ecology Letters 6:1056-1061.

Bruno, J. F., E. R. Selig, K. S. Casey, C. A. Page, B. L. Willis, C. D. Harvell, H. Sweatman and A. M. Melendy. 2007. Thermal stress and coral cover as drivers of coral disease outbreaks. Public Library of Sciences Biology 5:EL24.

Carricart-Gavnivet, J. A. 1998. Corales escleractinios, "piedra 
muscular" y San Juan de Ulúa, Veracruz. Ciencia y Desarrollo 141:70-73.

Chávez, E., J. W. Tunnel and K. Withers. 2007. Reef zonation and ecology: Veracruz shelf and Campeche bank. In Coral Reefs of the Southern Gulf of Mexico, W. Tunnel, E. A. Chávez and K. Withers (eds.). Texas University Press, Huston. p. 41-67.

Colwell, R. K. and J. Coddington. 1994. Estimating terrestrial biodiversity through extrapolation. Philosophical Transactions of the Royal Society of London, Series B 1311:101-118.

Connell, J. H. 1978. Diversity in tropical rain forests and coral reefs. Science 199:1302-1310.

Connell, J. H. 1997. Disturbance and recovery of coral assemblages. Coral Reefs 16:S101-S113.

Dustan, P. 1999. Coral reefs under stress: sources of mortality in the Florida Keys. Natural Resources Forum 23:147-155.

Garzón-Ferreira J., D. L. Gil-Agudelo, L. M. Barrios and S. Zea. 2001. Stony coral diseases observed in southwestern Caribbean reefs. Hydrobiologia 460:65-69.

Gotelli, N. J. and R. K. Colwell. 2001. Quantifying biodiversity: procedures and pitfalls in the measurement and comparison of species richness. Ecology Letters 4:379-391.

Gotelli, N. J. and J. L. Entsminger. 2005. EcoSim: null models software for ecology. Acquired Intelligence Inc and KeseyBear, Burlington. http://garyentsminger.com/ecosim/index. htm; last access: 03.II.2009.

Gómez, E. D., L. M. Cruz and K. A. Villamor. 2001. The science behind coral bleaching: priorities for research and management. In Coral bleaching: causes, consequences and response, H. Z. Schuttenberg (ed.). Coastal Resource Center, University of Rhode Island, Narragansett. p.12-30.

Guzmán, H. M. and C. A. Guevara. 1998. Arrecifes coralinos de Bocas del Toro, Panamá: distribución, estructura y estado de conservación de los arrecifes continentales de la Laguna de Chiriquí y la Bahía Almirante. Revista de Biología Tropical 46:601-623.

Graham, N. A. J., S. K. Wilson, S. Jennings, N. V. C. Polunin, J. P. Bijoux and J. Robinson. 2006. Dynamic fragility of oceanic coral reef ecosystems. Proceeding of the National Academy of Sciences USA 103:8425-8429.

Harvell, C .D., K. Kim, J. M. Burkholder, R. R. Colwell, P. R. Epstein, D. H. Grimes, E. E. Hofmann, E. K. Lipp, A. D. M. E. Osterhaus, R. M. Overstreet, J. W. Porter, G. W. Smith and G. R. Vasta. 1999. Emerging marine diseases - Climate links and anthropogenic factors. Science 285:1505-1510.

Harvell, C. D., C. E. Mitchell, J. R. Ward, S. Altizer, A. P. Dobson, R. S. Ostfeld and M. D. Samuel. 2002. Climate warming and disease risks for terrestrial and marine biota. Science 296:2158-2162.

Hernández-Delgado, E. A., B. Sandoz, M. Bonkosky, J. NoratRamírez and H. Mattei. 2008. Impacts of non-point source sewage pollution on Elkhorn coral, Acropora palmata
(Lamarck), assemblages of the southwestern Puerto Rico shelf. Proceedings of the $11^{\text {th }}$ International Coral Reef Symposium. p. 747-751

Horta-Puga, G. 2003. Condition of selected reef sites in the Veracruz reef System (stony corals and algae). Atoll Research Bulletin 496:360-369

Horta-Puga, G. and G. Barba-Santos. 2006. Veracruz Reef System, Gulf of Mexico. AGRRA Field Reports. htpp:// www.agrra.org; last access 06.III.2009.

Horta-Puga, G. 2007. Environmental impacts. In Coral reefs of the southern Gulf of Mexico, J. W. Tunnell, E. A. Chávez and K. Withers (eds.). J. W. Tunnel, E. A. Chávez and K. Withers (eds.). Texas University Press, Huston. p. 126-141.

Horta-Puga, G., M. Vargas-Hernández and J. P. CarricartGanivet. 2007. Reef Corals. In Coral Reefs of the Southern Gulf of Mexico, J. W. Tunnel, E. A. Chávez and K. Withers (eds.). Texas University Press, Huston. p. 95-101.

Humann, P. and N. DeLoach. 2001. Reef coral identification: Florida, Caribbean, Bahamas (Reef set Vol. 3). New World Publications, Jacksonville, Florida. 288 p.

Instituto Nacional de Ecología. 2005. Parque Marino Nacional, Sistema Arrecifal Veracruzano. Secretaría de Medio Ambiente, Recursos Naturales y Pesca, Comisión Nacional para el Conocimiento y Uso de la Biodiversidad, Mexico D. F. htpp://www.ine. gob.mx/ueajei/publicaciones/libros/2/sav. html; last access 30.III.2009

International Society for Reef Studies. 2004. Marine protected areas (MPAs) in management of coral reefs. International Society for Reef Studies, brief paper I. $13 \mathrm{p}$.

Jones, J., K. Withers and J.W. Tunnell Jr. 2008. Comparison of benthic communities on 6 coral reefs in the Veracruz Reef System (Mexico). Proceedings of the $11^{\text {th }}$ International Coral Reef Symposium. p. 757-760.

Loya, Y. 1972. Community structure and species diversity of hermatypic corals at Eilat, Red Sea. Marine Biology 13:100123.

Linton, D, R. Smith, P. Alcolado, C. Hanson, P. Edwards, R. Estrada, T. Fisher, R. Gomez-Fernandez, F. Geraldes, C. McCoy, D. Vaughan, V. Voegeli, G. Warner and J. Wiener. 2002. Status of coral reefs in the northern Caribbean and Atlantic node of the GCRMN. In Status of coral reefs of the world: 2002, C. Wilkenson (ed.). Australian Institute of Marine Science, Townsville. p. 277-302

Magurran, A. 2004. Measuring biological diversity. WileyBlackwell, Oxford.181 p.

Martínez, S. and A. Acosta. 2005. Cambio temporal en la estructura de la comunidad coralina del área de Santa Marta - Parque Nacional Natural Tayrona (Caribe Colombiano). Boletín de Investigaciones Marinas y Costeras - INVEMAR 34:161-191.

Martínez-Caballero, R. 2007. Geomorfología y caracterización biótica del Arrecife Sacrificios parque nacional Sistema 
Arrecifal Veracruzano, México. Thesis, Instituto Tecnológico de Boca del Río. Veracruz, 102 p.

Neter, J., M. H. Kutner, C. J. Nachtsheim and W. Wasserman. 1996. Applied linear statistical models. WBC McGraw-Hill, Massachusetts. 1408 p.

Nyenzi, B. and P. F. Lefale. 2006. El Niño Southern Oscillation (ENSO) and global warming. Advances in Geosciences 6:95101.

Nyström, M. and C. Folke. 2001. Spatial resilience of coral reefs. Ecosystems 4:406-417.

Ortiz-Lozano, L., A. Granados-Barba and I. Espejel. 2009. Ecosystemic zonification as a management tool for marine protected areas in the coastal zone: applications for the Sistema Arrecifal Veracruzano National Park, Mexico. Ocean \& Coastal Management 52:317-323.

Ostrander, G .K., K. M. Armstrong, E. T. Knobbe, D. Gerace and E. P. Scully. 2000. Rapid transition in the structure of a coral reef community: the effects of coral bleaching and physical disturbance. Proceeding of the National Academy of Sciences USA 97:5297-5302.

Pandolfi, J. M. 2002. Coral community dynamics at multiple scales. Coral Reefs 21:13-23.

Pastorok, R. A. and G. R. Bilyard. 1985. Effects of sewage pollution on coral reef communities. Marine Ecology Progress Series 21:175-189.

Porter, J. W. 1972. Patterns of species diversity in Caribbean reef corals. Ecology 53:745-748.

Porter J. W. and O. W. Meier. 1992. Quantification of loss and change in Floridian reef coral populations. American Zoologist 32:625-640.

Porter, J. W., P. Dustan, W. C. Jaap, K. L. Patterson, V. Kosmynin, O. W. Meier, M. E. Patterson and M. Parsons. 2001. Patterns of spread of coral disease in the Florida Keys. Hydrobiologia 460:1-24

R Development Core Team. 2005. R: a language and environment for statistical computing. http://www.R-project.org; last access 14.IV.2009.

Rangel-Avalos, M. A., L. K. B. Jordan, B. K. Walker, D. S. Gilliam, E. Carvajal-Hinojosa and R. E. Spieler. 2008. Fish and coral reef communities of the Parque Nacional Sistema Arrecifal Veracruzano (Veracruz Coral Reef System National Park) Veracruz, Mexico: preliminary results. Proceedings of the Gulf and Caribbean Fisheries Institute 60:427-435.

Richmond, M. H. 1993. Coral reefs: present problems and future concerns resulting from anthropogenic disturbance. American Zoologist 33:524-536.
Ronzón-Rodríguez, R. and J. M. Vargas-Hernández. 2007. Distribución, abundancia, patrones merísticos y mortalidad de las especies de Diploria en la llanura del arrecife de Sacrificios. In Investigaciones científicas en el Sistema Arrecifal Veracruzano, A. Granados-Barba, L. G. AbarcaArenas and J. M. Vargas-Hernández (eds.). Universidad Autónoma de Campeche, Campeche. p. 127-140.

Rosales-Hoz, L., A. Carranza-Edwards and O. Celis-Hernandez. 2007. Environmental implications of heavy metals in surface sediments near Isla de Sacrificios, Mexico. Bulletin of Environmental Contamination and Toxicology 78:353-357

Rosales-Hoz, L., A. Carranza-Edwards, L. Sanvicente-Añorve, M. A. Alatorre-Mendieta and F. Rivera-Ramirez. 2009. Distribution of dissolved trace metals around the Sacrificios Coral Reef Island, in the southwestern Gulf of Mexico. Bulletin of Environmental Contamination and Toxicology 83:713-719.

Roy, R. E. 2004. Akumal 's reefs: stony coral communities along the developing Mexican Caribbean coastline. Revista de Biología Tropical 52:869-881

Salas-Pérez, J. J. and A. Granados-Barba. 2008. Oceanographic characterization of the Veracruz Reef System. Atmósfera 21:281-301.

Sandin, S. A., J. E. Smith, E. E. DeMartini, E. A. Dinsdale, S. D. Donner, A. M. Friedlander, T. Konotchick, M. Malay, J. E. Maragos, D. Obura, O. Pantos, G. Paulay, M. Richie, F. Rohwer, R. E. Schroeder, S. Walsh, J. B. C. Jackson, N. Knowlton and E. Sala. 2008. Baselines and degradation of coral reefs in the Northern Line Islands. Public Library of Sciences One 3:EL1548.

Sebens, K. P. 1994. Biodiversity of coral reefs: what are we losing and why? American Zoologist 34:115-133.

Stirling, G. and B. Wilsey. 2001. Empirical relationships between species richness, evenness, and proportional diversity. American Naturalist 158:286-299.

Szmant, A. M. 2002. Nutrient enrichment on coral reefs: is it a major cause of coral reef decline? Estuaries 25:743-766.

Tunnel, J. W. 2007. Reef Distribution in Coral Reefs of the Southern Guf of Mexico. In Coral Reefs of the Southern Gulf of Mexico, W. Tunnel, E. A. Chávez and K. Withers (eds.). Texas University Press, Huston. p.14-22.

Vargas-Hernández, J. M., A. Hernández-Gutiérrez and L. F. Carrera-Parra. 1993. Sistema Arrecifal Veracruzano. In Biodiversidad Marina y Costera de México, S. I. SalazarVallejo and N. E. González (eds.). Comisión Nacional de Biodiversidad, Mexico D. F. p. 559-575. 
Appendix. Description of diseases and other syndromes detected at the reefs of Sacrificios and Santiaguillo, Veracruz Reef System Marine National Park, Mexico. Pictures by C.V. Gutiérrez-Ruiz and M.A.M. Román-Vives.

(A) White Plague Disease: This disease is recognized by tissue loss that begins at the base or margin of the colony, or next to a previously diseased area. A sharp line separates healthy tissue from the bare skeleton. A fine, but distinct, narrow band of bleached tissue may separate normal, fully pigmented tissue from the white, exposed skeleton. Two forms of White Plague have been described: White Plague type I and White Plague type II. The symptoms of both disease forms are similar, but the type II spreads more rapidly and may kill a coral colony in just one to two days; White Plague type I advances only a few millimeters each day. This disease is presumed to be a bacterial infection, although the pathogen remains unidentified (Humann and Deloach 2003). A colony of Montastraea cavernosa affected by this disease can be appreciated in the figure (A) at the end of the appendix.

(B) Bleaching: Bleaching results in the loss of the symbiotic algae (zooxanthellae) contained within coral tissue, or in the reduction of the photosynthetic pigments of the zooxanthellae that give the coral its normal color. In either case, the coral appears lighter in color, mottled or white. The causes of this bad coral condition are a widespread range of environmental stressors, such as increased water temperature, elevated solar radiation, sedimentation, pollution, increased salinity among others (Humann and Deloach 2003; Dahlgren 2005). A colony of Colpophyllia natans affected by this condition can be appreciated in the figure (B) at the end of the appendix.

(C) Tumors or irregular growths: Hyperplasy and neoplasy are included in this category. Hyperplasy is recognized as an area of the colony with accelerated growth of polyps, which results in distortion and other malformations of the colony. Neoplasy, on the other hand, is recognized as an irregular, calcified mass of skeleton that projects above the surface of the colony. It is covered with undifferentiated tissue that lacks symbiotic algae and the structural organization of normal tissue that makes individual polyps unrecognizable. This condition may slowly advance upward and outward as tissue in the center of the tumor dies (Humann and Deloach 2003). At the end of the appendix, hyperplasy can be appreciated on a colony of Colpophyllia natans (C1) and neoplasy on a colony of Montastraea cavernosa (C2).

(D) Dark-spot Disease: This disease can be identified as circular to irregular areas of pale discolored tissue with darkened polyps, or spots, in the middle of normal tissue and/or at the edge of the colony. Discolored tissue spreads as the affected tissue dies. The causes of this disease remain unknown (Humann and Deloach 2003; Santavy 2007). A colony of Siderastrea siderea affected by this disease can be appreciated in the figure (D) at the end of the appendix.

(E) Old Death: The coral colonies are covered with a thick layer of sediments and algae. Once this layer is taken off, the coral skeleton can be appreciated, showing signs that the death of polyps was not recent. This bad coral condition is probably associated with increased sedimentation. A colony of Montastraea cavernosa affected by this condition can be appreciated in the figure (E) at the end of the appendix.

(F) Paleness: This bad coral condition is evidenced by a paleyellow coloration at some parts of the colony, showing no bands in the surroundings of the affected tissue. The causes of this disease remain unknown, but could be a part of problems associated with bleaching. A colony of Montastraea cavernosa affected by this bad condition can be appreciated in the figure $(\mathrm{F})$ at the end of the appendix.
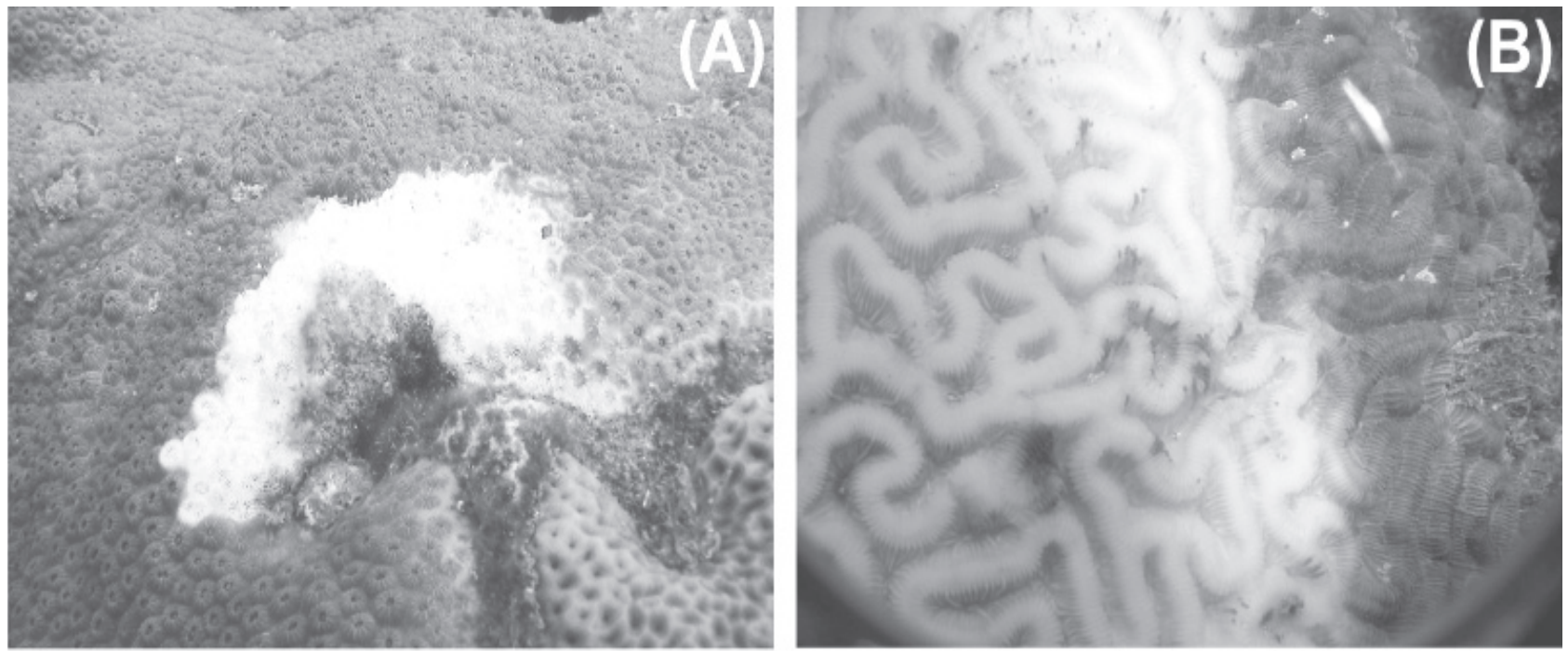

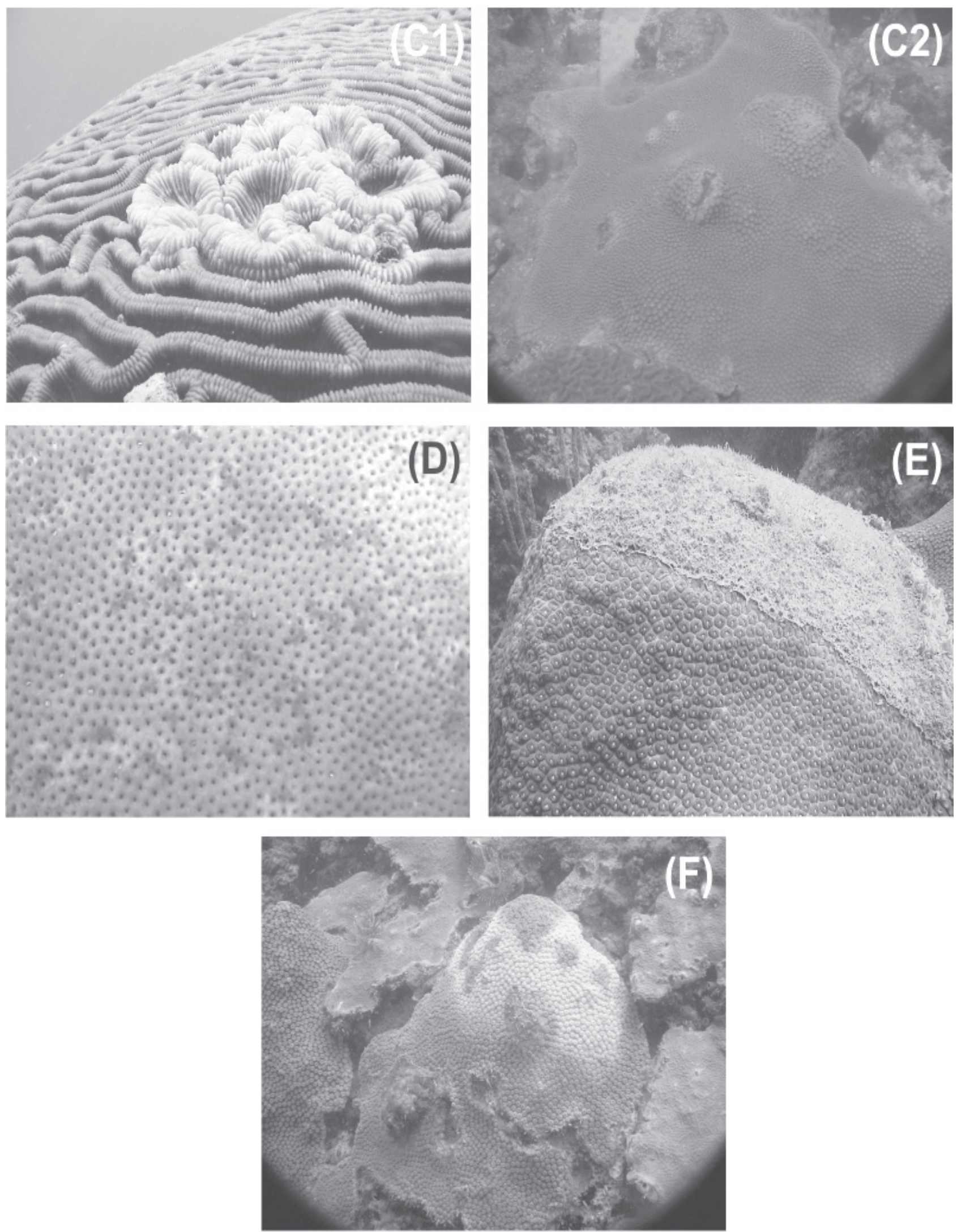